\title{
Immunological Emergency in Neonate: Case Report and Role of Early Screening
}

\author{
Veronica Mugarab Samedi, MD, PhD ${ }^{1,2,3}$ Amy Shafey, MD, FRCP2 Essa Al Awad, MD² \\ Luis Murguia Favela, MD, FRCP 3 \\ 1 Department of Neonatology, Peter Lougheed Hospital, Calgary, \\ Alberta, Canada \\ 2 Section of Neonatology, Foothills Medical Centre, University of \\ Calgary, Calgary, Alberta, Canada \begin{abstract}
Department of Neonatology, Peter Lougheed Hospital, 3500-26 Avenue, Calgary, Alberta T1Y 6J4, Canada

(e-mail: Veronica.Samedi@albertahealthservices.ca).
\end{abstract} \\ Address for correspondence Veronica Mugarab Samedi, MD, PhD,
}

${ }^{3}$ Faculty of Pediatrics, University of Calgary Cumming School of Medicine, Calgary, Alberta, Canada

Am J Perinatol Rep 2018;8:e134-e137.

Abstract
Keywords
- neonate
- immunodeficiency
- screening
- SCID
- stem cells
- TREC

Healthy looking newborns may have severe combined immunodeficiency (SCID), and neonatologists frequently are the first physicians to encounter these patients. Physicians usually have a high index of suspicion for this condition in presence of certain risk factors (unexplained infants' deaths, consanguinity); however, $>80 \%$ of infants with SCID have no positive family history. A timely diagnosis of this condition is crucial in decreasing both mortality and morbidity. The only way to detect SCID prior to the onset of infections is newborn screening (NBS). In term infants, NBS has $99.99 \%$ sensitivity for SCID, with no false negatives. In preterm infants, screening is less accurate due to a lack of standard $T$ cell receptor excision circle (TREC) values in this age group. We report a case of SCID in term infants born to consanguineous parents who were presented with clinical and laboratory findings of erythroderma, severe infection, failure to thrive, eosinophilia, and elevated immunoglobulin $\mathrm{E}(\mathrm{g} \mathrm{g})$ together with immunodeficiency. A timely diagnosis was followed by successful hematopoietic stem cell transplantation (HSCT) therapy.

Severe combined immunodeficiency (SCID) is a term for a group of life-threatening immune disorders caused by at least 15 different single genes. ${ }^{1,2}$ The incidence of SCID varies all over the world, and it is higher in countries where consanguinity is culturally accepted. Data from Saudi Arabia show SCID as 1:5,000 live births while those from the United States report an incidence of SCID rate of 1:5,00,000..$^{3,4}$ In Canada, SCID was traditionally considered a rare condition, but increased international migration may change this perception. ${ }^{5}$

Clinical presentation of SCID is very diverse. Immediately after delivery, affected infants may look well as the defect in their immunity is partially compensated by maternal antibodies. ${ }^{6}$ When this protection wanes during the first months of life, infants with SCID became extremely susceptible to both common (bacterial, viral, and fungal) and opportunistic pathogens. Thus, SCID is usually diagnosed after an infant has already acquired potentially life-threatening infection.,7 The only way to prevent the fatal outcome in these infants

received

October 4, 2017

accepted after revision

January 4, 2018 is early hematopoietic stem cell transplantation (HSCT) or, in some cases, gene therapy. Early initiation of treatment is crucial in decreasing both mortality and morbidity. ${ }^{6-8}$ During the first 3 months of life, HSCT is associated with a $95 \%$ rate of survival, while for older infants' survival after similar therapy reduces to $50 \%{ }^{6,9}$ Another serious risk of delayed SCID diagnosis is possible to overlap with vaccination when regular live vaccines as rotavirus or oral poliomyelitis could be lethal for infants with immunodeficiency. ${ }^{10}$

Therefore, timely diagnosis of SCID is a pediatric emergency. $^{3,6}$ In the last decade, the United States and some Canadian provinces made SCID screening a part of routine NBS to facilitate appropriate use of preventive measures (prophylactic antibiotic and immunoglobulin replacement therapy) as well as avoidance of live vaccines. ${ }^{6,11,12}$ As this screening is not universally administered all over North America, clinical awareness of possible SCID symptoms in a newborn is of high importance.

Copyright $\odot 2018$ by Thieme Medical Publishers, Inc., 333 Seventh Avenue, New York, NY 10001, USA. Tel: +1(212) 584-4662.
License terms

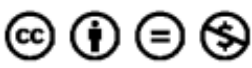




\section{Case Report}

Our patient is the first child of young consanguineous South Asian parents with no significant past medical history. Family history from both sides was unremarkable. Mother had regular prenatal follow-ups and used folic acid and prenatal vitamins. Her serologies were protective, and her regular fetal ultrasounds were assuring. She had no history of infections, flu-like symptoms, skin rashes, fever, or any other medical concerns during pregnancy. At 40 weeks of gestational age (GA), the mother went into labor, but was delivered by emergency cesarean section in view of fetal heart abnormalities and failure to progress. Her membranes were ruptured for 1 hour; amniotic fluids were with thick meconium. A male infant was delivered with a birth weight of 3,700 g, and APGAR score was 9 and 9 at 1st and 5th minute. Shortly after the delivery, the newborn developed respiratory distress and was admitted to the neonatal intensive care unit (NICU) with a provisional diagnosis of meconium aspiration.

At the time of admission, the infant was active, alert, not toxic, and not lethargic, with moderate tachypnea. His general examination was remarkable for generalized erythematous rash over the scalp, trunk, and limbs with dryness and desquamations on flexor area, no rash over the palms and feet, no pustules, vesicles, pigmentations, discharge, or erosions. Chest X-ray was done on admission ( - Fig. 1) and showed typical for meconium aspiration picture of bilateral diffuse grossly patchy

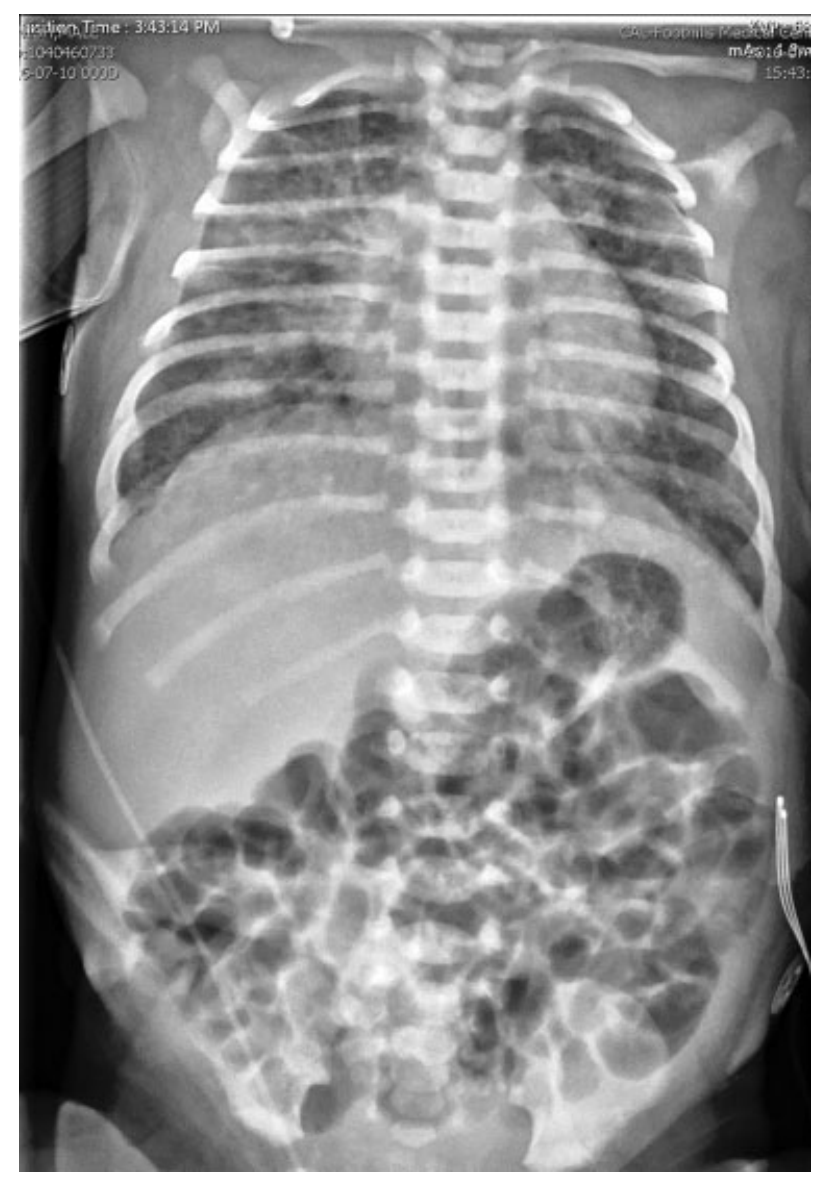

Fig. 1 Chest X-ray at DOL 1 showing absent Thymus. DOL, day of life. opacities (atelectasis and consolidation) and hyperinflation of lungs. There was no visible thymus shadow that was explained as a shrinkage secondary to delivery stress.

Sepsis work-up was done in view of clinical presentation, complete blood count (CBC) and differential showed mild eosinophilia, blood culture was reported as negative, and antibiotics were discontinued after 48 hours. His respiratory symptoms resolved within 12 hours after admission. There were no changes in skin rash appearance. Dermatology consultation was requested, and ichthyosis was suspected. Infants were started on humidification and emollient therapy and were referred for a diagnostic skin biopsy. Skin biopsy was performed on the day of life (DOL) 24 and showed mild hyperkeratosis with focal parakeratosis, overlying diffuse mild epidermal spongiosis, and absence of the granular layer. All these findings were non-conclusive for ichthyosis.

New concerns arose in the first month of life were decreased oral intake, frequent watery stools (10-12 times a day), and progressive weight loss (at the age of 1 month, his weight was $10 \%$ below his birth weight). He was admitted to a hospital with failure to thrive (FTT), diarrhea, and lethargy. On admission, he was hypoxemic (peripheral capillary oxygen saturation $\left[\mathrm{SpO}_{2}\right]$ of $70 \%$ on room air [RA]). Severe erythematous and the exfoliative rash was noted all over the scalp, face, body, and limbs. Full sepsis work-up was done, CBC showed significantly elevated white cell count with eosinophilia, and blood culture came positive for methicillin-resistant Staphylococcus aureus (MRSA) at 18 hours. CBC values are as shown in - Table 1.

Chest X-ray was remarkable for absent thymus shadow (-Fig. 2).

Immunology consultation was requested, and screening for immunodeficiency was performed (-Tables 2 and $\mathbf{3}$ ). It revealed dysimmunoglobulinemia with significantly elevated levels of Immunoglobulin E ( $\operatorname{IgE}$ ), and low levels of immunoglobulins $\mathrm{G}(\operatorname{IgG})$ and $\mathrm{M}(\operatorname{IgM})$. Further genetic testing confirmed recombination activating gene 2 (RAG2) gene mutation.

Table 1 CBC, differential during first month of life showing worsening neutrophilia and eosinophilia

\begin{tabular}{|l|l|l|l|}
\hline & DOL 1 & DOL 3 & DOL 30 \\
\hline Hematocrit & 0.49 & 0.51 & 0.43 \\
\hline Platelets count & 183 & 180 & 120 \\
\hline WBC & $23.3^{\mathrm{a}}$ & $27.1^{\mathrm{a}}$ & $79.5^{\mathrm{a}}$ \\
\hline Neutrophils & 9.8 & 5.4 & 8 \\
\hline Lymphocytes & 5.4 & 10.6 & 52.5 \\
\hline Monocytes & 0.9 & 1.6 & 4 \\
\hline Eosinophils & $5.8^{\mathrm{a}}$ & $8.7^{\mathrm{a}}$ & $13.5^{\mathrm{a}}$ \\
\hline Myelocytes & 0.2 & & \\
\hline Metamyelocytes & 1.2 & 0.8 & \\
\hline
\end{tabular}

Abbreviations: CBC, complete blood count; DOL, day of life; WBC, white blood count.

${ }^{\mathrm{a}}$ Abnormal values. 


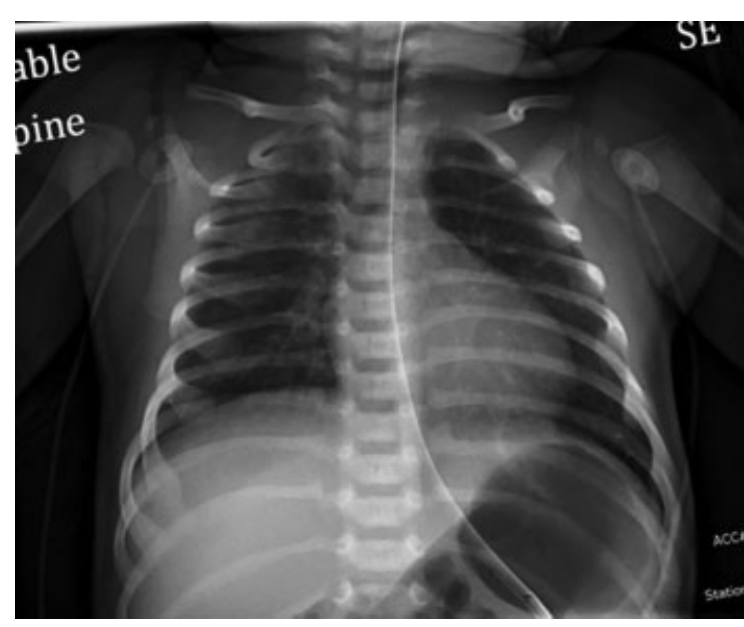

Fig. 2 Chest X-ray on DOL 30. DOL, day of life.

Table 2 Immunoglobulins levels at 1 month of life

\begin{tabular}{|l|l|l|}
\hline & Patient & Normal \\
\hline $\mathrm{IgC}$ & $0.69 \mathrm{~g} / \mathrm{L}$ (Low) & $2.6-14 \mathrm{~g} / \mathrm{L}$ \\
\hline $\mathrm{IgA}$ & $0.14 \mathrm{~g} / \mathrm{L}$ & $0.0-1.2 \mathrm{~g} / \mathrm{L}$ \\
\hline $\mathrm{IgM}$ & $<0.01 \mathrm{~g} / \mathrm{L}$ (Low) & $0.14-1.4 \mathrm{~g} / \mathrm{L}$ \\
\hline $\mathrm{IgE}$ & $3653 \mathrm{kIU} / \mathrm{L}$ (High) & $8-117 \mathrm{kIU} / \mathrm{L}$ \\
\hline
\end{tabular}

Abbreviations: IgA, immunoglobulin A; IgE, immunoglobulin E; $\mathrm{IgG}$, immunoglobulin $\mathrm{G}$.
Combination of clinical and laboratory findings of erythroderma, severe infection, failure to thrive, eosinophilia, and elevated IgE together with immunodeficiency and RAG2 gene mutation met the diagnostic criteria of T cell-negative, B cell-negative, natural killer-positive (T-B-NK + ) SCID consistent with Omenn syndrome.

Complex treatment was started as a preparation for HSCT therapy: cyclosporine and prednisone were started on DOL 31 to target clonal $\mathrm{T}$ cell population, Septra was started as Pneumocystis jiroveci pneumonia (PJP) prophylaxis, and fluconazole as fungal prophylaxis. Skin lesion improved within the first week of treatment, diarrhea and feeding intolerance resolved, and infant started to gain weight. Human leukocyte antigen (HLA)-typing found the mother to be 10/10 match bone marrow donor, and he underwent successful HSCT therapy.

\section{Discussion}

Healthy looking newborns may have SCID, and neonatologists frequently are the first physicians to encounter these patients. Maternal immunoglobulins, both transplacental IgGs and breast milk IgAs, can protect newborn from common infections in the first months of life. ${ }^{3}$ As this protection wanes by the age of 3 to 4 months, rising symptoms of immunodeficiency (erythroderma, hepatosplenomegaly, lymphadenopathy viral and fungal pneumonitis, opportunistic infections [Pneumocystis, CMV, and parainfluenza], chronic diarrhea, and failure to thrive) provide clinical clues

Table 3 Immunodeficiency screening panel

\begin{tabular}{|c|c|c|c|c|}
\hline Lymphocyte subsets & $\%$ of Lymphocytes & $\begin{array}{l}1 \text { week to } 2 \text { months } \\
\text { reference range }\end{array}$ & ABS count $\times 10^{9} / \mathrm{L}$ & $\begin{array}{l}1 \text { week to } 2 \text { months } \\
\text { reference range }\end{array}$ \\
\hline $\begin{array}{l}\text { CD3 } \\
\text { (T cells) }\end{array}$ & 94.1 & $55-90$ & 28.410 & $1.900-8.400$ \\
\hline $\begin{array}{l}\text { CD3 + CD16/56+ } \\
\text { (NK-like T cells) }\end{array}$ & 02.1 & $0-1$ & 0.63 & $0.007-0.091$ \\
\hline $\begin{array}{l}\text { CD3 }+4+ \\
\text { (Helper T cells) }\end{array}$ & 44.5 & $39-69$ & 13.450 & $1.500-6.00$ \\
\hline $\begin{array}{l}\text { CD3 + 8+ } \\
\text { (Suppressor/cytotoxic T cells) }\end{array}$ & 50.3 & $7-35$ & 15.190 & $0300-2.700$ \\
\hline $\begin{array}{l}\text { CD3 + 4-8- } \\
\text { (Double negative T cells) }\end{array}$ & 00.2 & & 0.050 & \\
\hline CD4/CD8(ratio) & 0.89 & $1.3-6.3$ & & \\
\hline $\begin{array}{l}\text { CD19 } \\
\text { (B cells) }\end{array}$ & 00.0 & $03-6-$ & 0.000 & $0.18-3.50$ \\
\hline $\begin{array}{l}\text { CD3-CD16/56+ } \\
\text { (NK cells) }\end{array}$ & 05.3 & $3-23$ & 1.610 & $0.140-1.900$ \\
\hline \multicolumn{5}{|l|}{$\begin{array}{l}\text { T-helper subsets } \\
\text { (\% of CD3) }\end{array}$} \\
\hline $\begin{array}{l}\mathrm{CD} 3+4+\text { CD45RA + CD27+ } \\
\text { (Naïve) }\end{array}$ & 001 & $66-100$ & 0.081 & $1.200-5.700$ \\
\hline $\begin{array}{l}\mathrm{CD} 3+4+\mathrm{CD} 45 \mathrm{RA}+\mathrm{CD} 27- \\
\text { (Terminally differentiated) }\end{array}$ & 001 & $<1.0$ & 0.194 & $0.000-0.002$ \\
\hline $\begin{array}{l}\text { CD3 }+4+\text { CD45RA-CD27+ } \\
\text { (central memory) }\end{array}$ & 041 & $4-41$ & 5.566 & $0.090-1.700$ \\
\hline $\begin{array}{l}\text { CD3 + } 4+\text { CD45RA-CD27- } \\
\text { (Effector memory) }\end{array}$ & 057 & 1.0 & 7.610 & $0.000-0.026$ \\
\hline
\end{tabular}


in diagnosing this pediatric emergency. ${ }^{3,6,9}$ Delay in diagnosis and treatment of SCID causes significant morbidity and mortality from recurrent infections. ${ }^{9-11}$ Untreated, almost $100 \%$ of infants with SCID will die within 18 months of life. ${ }^{8,10}$ Thus, early identification of this condition via newborn screening (NBS) is extremely important.

At the present time, the only assay that provides adequate sensitivity and specificity in detecting SCID is the T cell receptor excision circle (TREC) assay, proposed by Chan and Puck in 2005. ${ }^{13}$ The idea of screening came from the fact that at birth TREC level represent around $10 \%$ of total T cell numbers. Thus, infants with SCID would have very low or undetectable TRECs numbers. Even presence of maternal T cells in an infant with SCID would not change TREC count to the normal values because maternal cells have very few TRECS. Therefore, number of TRECs is a unique biomarker that gives an opportunity for pre-symptomatic diagnosis of SCID. ${ }^{13,14}$ Routine screening of all newborns with the TREC test already implemented as part of public health program in many countries, including some provinces of Canada. Early detection of SCID is a valuable resource for physicians to provide effective treatment and prevent the severe complication of this life-threatening syndrome.

\section{Conflict of Interest}

None.

\section{References}

1 Buckley RH. Molecular defects in human severe combined immunodeficiency and approaches to immune reconstitution. Annu Rev Immunol 2004;22:625-655

2 Notarangelo LD, Fischer A, Geha RS, et al; International Union of Immunological Societies Expert Committee on Primary Immunodeficiencies. Primary immunodeficiencies: 2009 update. J Allergy Clin Immunol 2009;124(06):1161-1178
3 Rosen FS. Severe combined immunodeficiency: a pediatric emergency. J Pediatr 1997;130(03):345-346

4 Suliaman F, Al-Ghonaium A, Harfi H. High incidence of severe combined immune deficiency in the Eastern Province of Saudi Arabia. Pediatr Asthma Allergy Immunol 2006;19(01):14-18

5 Griffith LM, Cowan MJ, Notarangelo LD, et al; Workshop Participants. Improving cellular therapy for primary immune deficiency diseases: recognition, diagnosis, and management. J Allergy Clin Immunol 2009;124(06):1152-60.e12

6 Newborn Screening for Severe Combined Immunodeficiency Disorder. Secretary's Advisory Committee on Heritable Disorders in Newborns and Children; 2011. Available from: http://www.hrsa. gov/advisorycommittees/mchbadvisory/heritabledisorders/recom mendations/correspondence/combinedimmunodeficiency.pdf. Accessed August 3, 2017

7 Myers LA, Patel DD, Puck JM, Buckley RH. Hematopoietic stem cell transplantation for severe combined immunodeficiency in the neonatal period leads to superior thymic output and improved survival. Blood 2002;99(03):872-878

8 Brown L, Xu-Bayford J, Allwood Z, et al. Neonatal diagnosis of severe combined immunodeficiency leads to significantly improved survival outcome: the case for newborn screening. Blood 2011;117(11):3243-3246

9 Notarangelo LD, Fischer A, Geha RS, et al; International Union of Immunological Societies Expert Committee on Primary Immunodeficiencies. Primary immunodeficiencies: 2009 update. J Allergy Clin Immunol 2009;124(06):1161-1178

10 Patel NC, Hertel PM, Estes MK, et al. Vaccine-acquired rotavirus in infants with severe combined immunodeficiency. N Engl J Med 2010;362(04):314-319

11 Chase NM, Verbsky JW, Routes JM. Newborn screening for SCID: three years of experience. Ann N Y Acad Sci 2011;1238:99-105

12 Routes JM, Grossman WJ, Verbsky J, et al. Statewide newborn screening for severe T-cell lymphopenia. JAMA 2009;302(22):2465-2470

13 Chan K, Puck JM. Development of population-based newborn screening for severe combined immunodeficiency. J Allergy Clin Immunol 2005;115(02):391-398

14 Puck JM; SCID Newborn Screening Working Group. Populationbased newborn screening for severe combined immunodeficiency: steps toward implementation. J Allergy Clin Immunol 2007;120(04):760-768 